\title{
Torre de Marfim - Um panorama sobre a mercantilização do ensino superior nos Estados Unidos
}

Katya Zuquim Braghini

Doutora e Mestre em Educação pela Pontifícia Universidade Católica de São Paulo (PUC-SP). Bacharel e Licenciada em História pela Universidade de São Paulo.

E-mail: katya.braghini@yahoo.com.br

Resumo: Torre de Marfim é um filme que mostra um processo de meio século de desmantelamento das linhas de subsídio público aos estudantes do ensino superior nos Estados Unidos e o paulatino aumento dos financiamentos privados que acabam por transformar os recém-formados em devedores antes mesmo de seres trabaIhadores. Deixa evidente o estilo de mercantilização da educação superior no país como um processo histórico que ao mesmo tempo prega o consumo dos aparelhos estudantis; a busca incessante por prestígio social e a progressiva decomposição do modelo de graduação residencial, tão caro à tradição educacional estadunidense.

Palavras-chave: mercantilização do ensino, ensino superior, financiamento educacional, inovação educacional, graduação.
Abstract: Ivory Tower is a film that shows a half century process of dismantling of the public subsidy lines to higher education students in the United States and the gradual increase in private funding that transforms new graduates in debtors even before they are workers. It makes clear the commodification style of higher education in the country as a historical process that simultaneously preaches the consumption of student devices; the relentless pursuit of social prestige and the gradual decomposition of the residential graduation model, so dear to the American educational tradition.

Keywords: commodification of education, university education, educational financing, educational innovation, graduation.

Torre de Marfim é um documentário sobre o processo de mercantilização do ensino superior nos Estados Unidos. Esse processo é percebido no movimento social que desmerece as possibilidades de ensino superior gratuito; valoriza projetos alternativos informatizados que à primeira vista se mostram como uma "face do bem"; desmantela as ações públicas de subsídios para estudos e cria o crédito educativo privado. No filme, a expressão "Torre de Marfim”, por um lado, diz respeito à exclusividade, autoridade, legitimidade e prestígio que 
marcam a comunidade acadêmica de alto nível nos EUA. Por outro, ironiza com as diversas situações estruturais e conjunturais que, atualmente, abalam a aura mítica criada em torno de tais instituições.

Em 97 minutos, o filme apresenta um panorama geral do ensino superior se concentrando em alguns focos: a) Na capitalização das principais institutos de ensino superior no pais; b) $\mathrm{O}$ processo de endividamento dos jovens por meio dos créditos estudantis; c) A apresentação de "alternativas" educacionais diante do modelo empresarial de universidade.

O filme tece um panorama histórico das diversas modalidades de ensino superior existentes e demonstra, com gravidade, o processo de estratificação social que distancia cada vez mais os jovens pobres das universidades socialmente prestigiosas. Em 2011, cerca de $75 \%$ por cento dos estudantes nas duzentas escolas mais bem classificadas do país vieram de famílias do quartil superior de renda. Apenas $5 \%$ são de famílias do quartil inferior. A pergunta de fundo do filme é: Qual é o papel da universidade diante da desigualdade de renda sem precedentes na história dos Estados Unidos?

São apresentados dois grandes exemplos da mercantilização do sistema. O primeiro é apontado por Clayton Christensen autor do livro Innovators Dilemma, destacando a Universidade de Harvard (Private School). A primeira instituição superior do país, fundada em 1639, seria a base DNA de quase toda a educação superior nos EUA, e como modelo, acelerou uma corrida que estimulou, acima de tudo, a competição entre escolas. A corrida por prestígio social faz com que as universidades concentradas em State Colleges e Private Colleges modificassem os seus currículos, inventando novos aparelhos didáticos, e passassem por um monumental processo de edificação de novas instalações. Algumas delas se tornaram verdadeiros parques temáticos na tentativa de acompanhar todas as possibilidades curriculares que inventam e atrair mais alunos para a sua comunidade.

A Arizona State University é um dos exemplos apontados para este caso. É reconhecida nacionalmente por ser uma "party school" dentro de um ranking feito pela revista Plaboy. Explicando: a universidade permite que os alunos façam muitas festas e ao apresentar-se como espaço de socialização festiva, tem sido acusada de capitalizar sobre as atividades de entretenimento. Internamente, as festas geram um currículo visível de segregação, pois os alunos mais influentes vivem em luxuosas moradias no campus e ali organizam eventos que não é aberto a todos. Segundo Ricardo Arum, autor do livro Academically Adrift: Limited Learning on College Campuses essas distrações, para quem pode pagá-las, gerou a diminuição das horas de estudos dos graduandos, que em 2012 estudaram menos de cinco horas por semana (36\%). Nas universidades públicas $68 \%$ dos estudantes frustraram-se na graduação de 4 anos; $44 \%$ falharam na graduação de 6 anos. Esse atraso na formação é imediatamente relacionado ao custo.

Essa realidade que associa a educação superior ao lucro destemido foi o resultado de um lento processo de retirada do Estado como mantenedor do bem-estar. Iniciado pelas reformas do New Deal implantado por Franklin 
Roosevelt (1933-1937); passando pelo Higher Education Act assinado por Lyndon Johnson (1965) que ainda determinava o financiamento de alunos após o ensino secundário; desembocou em Ronald Reagan afirmando que a curiosidade intelectual seria uma afronta ao contribuinte. Nos anos 1980 o acesso dos pobres na universidade caiu. O termo gratuito passou a ser amaldiçoado.

A Federal Pell Grant, o financiamento público para faculdades diminuiu, na mesma medida que aumentam as linhas de crédito estudantis privadas. As famílias se endividam e os créditos se beneficiam. As perdas de investimentos governamentais foram repassados aos alunos. Atualmente, a soma total de débitos estudantil chegou a 1 trilhão de dólares. As dívidas de crédito educacionais são mais lucrativas do que qualquer outro tipo de financiamento, imobiliário ou empresarial, porque, no caso dos ex-alunos, não há execução de dívida e nem decreto de falência. Os juros das dívidas são contabilizados do débito geral, desencadeia-se a cobrança de juros sobre juros, o que resulta em dívidas que podem seguir para o resto da vida.

Desse movimento primordial, surgem discussões sobre as possibilidades alternativas de ensino, ou de como educar um maior número de alunos, sem ter mais custos, de forma a transformar esse plano em mais uma vitrine para a instituição. Uma parte das alternativas é vendida como a mais moderna forma de currículo amparada por veículos tecnológicos virtuais. Outras são situações imaginadas entre o idílico e o segregacionista.

No caso do uso de tecnologia virtual há dois movimentos opostos, mas relacionados, que tem por cartão de visitas, empresas do Sillicon Valley e são amparadas por instituições superiores tais como a University of California, Stanford University. Às vezes temos a impressão que esses modelos educacionais informatizados foram mostrados como boas formas alternativas diante do problema de distribuição de educação em massa. Mas, no discorrer do filme percebemos que, nem tanto. Seus idealizadores registram esse fenômeno com relativa clareza, mas não constroem uma narrativa tão aderente ao fato.

O movimento UnCollege fundado por Dale Jasper Stephens estimula jovens a sair de suas faculdades para hackear a sua educação, ou seja, a desconsiderar a necessidade de ensino superior para se obter sucesso. Trata-se de pequenos grupos autogestores, instalados no Vale do Silício e que estudam por meio de mecanismos livres de conhecimento na internet. Buscam inspiração em sujeitos como Steve Jobs (Apple), Bill Gates (Microsoft), Mark Zuckerberg (Facebook). Acreditam em um tipo de conhecimento que é experiencial, prático, mas que tem inspiração no ideal individual de conquista de um patrimônio e ganho financeiro.

Peter Thiel fundador do sistema automático de pagamento PayPal chegou a oferecer 100 mil dólares para os alunos que abandonassem as suas universidades e se juntassem ao movimento, estabelecendo um novo tipo de filantropia para estudos: aquela que financia jovens talentos que não pagariam uma universidade e acreditam nas possibilidades empreendedoras informatizadas. Essa proposta é criticada pelos especialistas ao menos por três vias. Uma que desconsidera a

3. APARICI, Roberto (org.). Educomunicação: mais além dos 2.0. São Paulo: Paulinas Editora, 2014. 
4. SOARES, Ismar de Oliveira. Educomunicação: 0 conceito, o profissional, a aplicação. São Paulo: Paulinas Editora, 2011.

5. CITELLI, Adilson; COSTA, Maria Cristina (orgs.). Educomunicação: construindo uma nova área de conhecimento. São Paulo: Paulinas Editora, 2011.

6. CITELLI, Adilson Odair (org). Educomunicação: imagens do professor na mídia. São Paulo: Paulinas Editora, 2012. perda de prestígios das universidades como base formadora para o trabalho; depois, há críticas ao movimento por considerar o sucesso financeiro em objetivo educacional e, por fim, implicitamente, critica-se o empreendedorismo como a forma evidente da abdicação do Estado e dos adultos na educação dos jovens. Os críticos dizem que esses jovens não se beneficiam da vivência universitária, voltando-se para uma atitude focada no autoconhecimento, tornando-se egocêntricos.

Há também movimentos ligados aos processos de informatização institucionalizados, como o da Universidade de Stanford. O Massive Open Online Courses (MOOCs) permite acesso ilimitado, gratuito, de pessoas do mundo inteiro ao conteúdo produzido pela Universidade por meio de cursos on-line. A ideia inicial era que fosse distribuído conteúdo sofisticado sem certificação, sem taxas para pagar, sem matrícula. Essas plataformas virtuais usam vídeos curtos, bate-papos e veiculam os mais variados assuntos para um grande público. Daphne Koller foi a professora idealizadora do projeto. Posteriormente, ela e seus colegas, dentre eles, Peter Norvig, fundaram a Udacity (2011) e a Cousera (2012), ambas com os mesmos objetivos, só que agora, na qualidade de empresas. Na costa leste, existe a EdX com o mesmo propósito, surgida da união entre o Massachusetts Institute of Technology (MIT) e a Harvard University.

No caso da Califórnia o governador Jerry Brown Jr. foi buscar ajuda de Peter Norvig/Udacity para que ele educasse os alunos que se atrasavam na graduação. O ensino superior da Califórnia é multidistribuído e diversificado, mas os índices educacionais de desempenho estão caindo. A Universidade de San Jose foi uma das entidades que fechou uma parceria com a Unacity para o atendimento do grupo com baixo desempenho escolar.

Os professores da própria instituição criticaram a parceria porque, segundo eles, o ensino virtual não deveria ser oferecido com o dinheiro do contribuinte. Para o grupo, a parceria, além de atacar o modelo de universidade pública que deve estar aberto a todos, estava criando a segregação dos alunos em dois grupos: o primeiro, abastecido por capital social e cultural, continuava com o privilégio dos encontros presenciais com os professores; os outros, atrasados, recorriam ao YouTube. Ao final o rendimento dos jovens a partir das plataformas não foi o esperado e a parceria foi suspensa. Isso porque, embutido a ideia de autogestão do conhecimento, há a necessidade de disciplina, motivação e persistência que não necessariamente foi estimulada pelo intermédio com a máquina.

No caso de Harvard, as ferramentas virtuais estão distribuídas por todo o campus, mas o uso do EdX está centrado no curso mais popular na Universidade no momento, o CS50. Trata-se de um curso de introdução à programação de computadores para quem não necessariamente tem a experiência. O curso se utiliza da plataforma para distribuição e aquisição de conhecimentos, tem aulas na forma de espetáculos de auditório, possui "seguidores" e também aposta na mística das maravilhosas novidades da internet.

Existe um conceito ligado à plataforma EdX chamado "sala de aula invertida”. Escolas, cursos, outras universidades, em qualquer local do mundo, 
podem acessar vídeos produzidos por eles com conhecimento reforçado pelo MIT. Após a aula em vídeo, os grupos que podem estar em qualquer local do mundo discutem as informações, teoria, conceitos etc..

No caso da Universidade de San Jose a promessa de uma pílula mágica que estimulasse o ensino por meio de recursos virtuais não foi um sucesso, fazendo valer a ideia de que luxuoso é ter um professor presencial. Mesmo as aulas do CO50 de Harvard demonstram que os alunos necessitam de colaboração presencial. De todo modo, a tecnologia virtual é uma esperança de educação superior para o atendimento massivo e com baixos custos. As instituições norte-americanas, governamentais, de ensino e pesquisa têm pensado em como fundamentar alternativas educacionais chamadas de "ensino híbrido" (Blended Learning), isso é, propostas que valorizem ações on-line presenciais, também apresentadas pelo termo off-line.

Diz-se que o seu currículo universitário estadunidense tem o seu radical envolvido no pensamento protestante puritano que forja a construção de sujeitos com o caráter prático, que seja útil para a sua comunidade ao longo da vida. Tal princípio educacional está atrelado a uma visão moderna do sermão como compromisso de que a vida, para ser vivida, tem que ter um propósito.

$\mathrm{Na}$ busca por um propósito que esteja alheio ao excesso de capitalização do universo acadêmico, foram apresentados alguns exemplos durante o filme, e aqui nos concentramos em dois deles.

A Universidade Deep Springs se baseia nos seguintes três pilares: autogoverno, estudos e trabalho. A instituição não é luxuosa, as salas são pequenas, os alunos usam livros, as aulas são com grupos pequenos, e ela se localiza no Vale da Morte na Califórnia. Segundo o regimento, os jovens assumem um comprometimento com a comunidade e os estudantes pareçem felizes e estudiosos.

Outro caso é a Cooper Union em Nova York, até o ano passado, um dos exemplos de educação superior gratuita dos Estados Unidos, pautada por princípios de educação a todos. Ela faz parte de um rol de escolas fundadas por filantropos, como Peter Cooper, preocupados com educação de imigrantes, pobres, membros da classe trabalhadora que se desenvolveram no século XIX. Este ano, a Universidade passou a cobrar mensalidade dos alunos. Segundo os seus alunos, ter sido gratuita significava honestidade para com a tradição e o histórico da escola, bem como, ter um modelo diferencial na conjuntura atual. No final do filme, os alunos da Cooper Union mostram otimismo ao julgar que a batalha não está perdida. O questionamento implícito com a história é: por que uma instituição tradicional, histórica e gratuita está sendo lançada para a obsolescência?

Esses dois exemplos são melancólicos. Mostram a força dos discursos hegemônicos desqualificando as escolas com currículos que, de uma forma ou de outra, se apegariam ao passado. A primeira está parada no tempo, a segunda, engolida por este tempo. São tipos outsiders de Universidades.

Mas, triste mesmo é perceber uma parcela da juventude se sentido enganada com todo esse processo histórico. Sentem-se desiludidos porque acreditaram
7. OROZCO GÓMEZ, Guillermo. Educomunicação: recepção midiática, aprendizagens e cidadania. São Paulo: Paulinas Editora, 2014.

8. APARICl, Roberto (org.). Educomunicação: mais além dos 2.0. São Paulo: Paulinas Editora, 2014. 
na promessa de futuro feliz, caso seguissem pelo ensino superior. Os seus pais se preocupam, porque investem caro e não querem recebê-los de volta ao lar, desempregados. Temem pela quebra de um dos ritos sociais mais valorizados na sociedade estadunidense: a retirada dos filhos para o mundo adulto após o seu período de graduação. Jovens se formam e são devedores antes de assumirem uma função profissional. E como o sucesso profissional passou a ser compreendido como sucesso de vida, quando isso não acontece, a frustração é grande.

O filme não se aprofunda nas explicações sobre o funcionamento do sistema universitário norte-americano, porque foi produzido pela CNN Films e leva em conta o entendimento de quem é nativo. Não mostra claramente a educação superior em suas diferentes acepções e modelos. Também não se ocupa em apresentar o outro lado da questão, sobre o sucesso na formação de seu quadro científico etc. Concentra-se em mostrar um fenômeno social que está modificando o respeitado modelo universitário de graduação residencial.

Vale a sessão para que não deixemos de lado os debates em torno do processo de mercantilização do ensino superior no Brasil. Estudar as nossas próprias características e o que se tem produzido de fantasmas sociais em nossa própria sociedade. Ou melhor, como a atual comercialização do ensino superior brasileiro é em si mesmo a marca evidente de uma cultura segregacionista e quanto o alimentamos com critérios esdrúxulos de ensino, formas de fazer criadas para reforçá-lo, a partir de uma autoridade ilustrada.

É possível fazer qualquer coisa com a Educação (e não só com ela) se o objetivo é ganhar dinheiro, deixa a entender o filme. A concepção de novos recursos para o ensino em massa mostra explicitamente a criação de monopólios capitalistas abraçados pelas instituições de ensino como necessidades sem retorno. Paga-se muito por uma ideia de "educação do futuro" atrelado a um sistema de objetos. O que criamos e adaptamos para a escola com o caráter de "inovação" também é uma escolha. Tem-se a impressão que o futuro é imenso e que a informática e o entretenimento, em vez de recursos, passam a critérios fundamentais de indicação da qualidade de ensino. Não é a primeira vez que um excesso de coisas é o centro da atividade pedagógica... Mas isso é outra história. Aqui se trata de entender um processo particular de comercialização educacional que dá muita ênfase ao que se proclama como inovador e esquece-se de fazer crítica do aparato completo: quem vende esses produtos? Como eles são oferecidos a nós? Que espécie de currículo ele imprime nas pessoas? Quem são essas empresas? Que espécie de críticas se faz quando novas invenções pedagógicas são transformadas em critérios de educação de qualidade?

No filme as possíveis soluções para os problemas educacionais e os novos processos de aprendizagem criados não mais se dissociam da capacidade técnica das universidades em transformar a sua aparelhagem em bem de consumo. Currículos são pré-estabelecidos pensando na constituição de novos consumidores, gerando a necessidade de novos espaços, novos implementos, novos recursos, e um imperativo pedagógico que liga a boa educação a uma ou outra empresa ou a um cartel delas. E alguns educadores estão acompanhando tudo isso, 
ávidos por criar novas categorias de pensamento e a resignificar termos antigos para formatar esse modelo de escola. Formar o pensamento crítico e produzir conhecimento essa é uma tradição da educação superior norte-americana que o filme exibe com orgulho. A angústia é que ela é apresentada como uma espécie de doente em busca de recuperação.

\section{REFERÊNCIAS}

ARUM, Richard, ROKSA, Josipa. Academically Adrift: Limited Learning on College Campuses. University of Chicago Press, 2001.

CHRISTENSEN, Clayton. The Innovator's Dilemma: When New Technologies Cause Great Firms to Fail. Harvard Business Review Press, 1997.

\section{Filme}

Torre de Marfim (Ivory Tower)

Direção e roteiro: Andrew Rossi

Fotografia: Andrew Rossi/Bryan Sarkinen/Andrew Coffman

Música: Ian Hultquist

Gênero: documentário

Ano: 2014

Noruega 